\title{
THE MARINE LEECH Stibarobdella loricata (HARDING, 1924) (HIRUDINEA, PISCICOLIDAE), PARASITIC ON THE ANGEL SHARK Squatina spp. AND SANDTIGER SHARK Carcharias taurus RAFINESQUE, 1810 (CHONDRICHTHYES: SQUATINIDAE, CARCHARIIDAE) IN SOUTHERN BRAZILIAN WATERS
}

\author{
SOTO, J. M. R. \\ Museu Oceanográfico do Vale do Itajaí, MOVI, Universidade do Vale do Itajaí, UNIVALI, \\ Rua Uruguai, 458, CEP 88302-202, Itajaí, SC, Brazil \\ Correspondence to: Jules M. R. Soto, Museu Oceanográfico do Vale do Itajaí, MOVI, Universidade do Vale do \\ Itajaí, UNIVALI, Rua Uruguai, 458, CEP 88302-202, Itajaí, SC, Brazil, e-mail: soto@bc.univali.br \\ Received April 1, 2002 - Accepted August 27, 2002 - Distributed November 30, 2003
}

(With 4 figures)

\begin{abstract}
The presence of the marine leech, Stibarobdella loricata (Harding, 1924) (Hirudinea, Piscicolidae), is reported on the southern coast of Brazil, based on seven lots with 47 specimens, between 71 and $182 \mathrm{~mm}$ in total length, collected on the dorsal region of angel sharks, Squatina argentina (Marini, 1930); S. guggenheim Marini, 1936; S. punctata Marini, 1936 (Chondrichthyes, Squatinidae); and on the head of a sandtiger shark, Carcharias taurus Rafinesque, 1810 (Chondrichthyes, Carchariidae). This is the first record of $S$. loricata in the western Atlantic and of its parasitic association with $S$. argentina, $S$. guggenheim, S. punctata, and C. taurus.
\end{abstract}

Key words: Stibarobdella loricata, Squatina spp., Carcharias taurus, Hirudinea, Chondrichthyes, ectoparasitism.

\section{RESUMO}

A sanguessuga marinha Stibarodella loricata (Harding, 1924) (Hirudinea, Piscicolidae), parasita do cação-anjo Squatina spp. e do tubarão-mangona Cacharias taurus Rafinesque, 1810 (Chondrichthyes: Squatinidae, Carchariidae) em águas do sul do Brasil

É assinalada a presença da sanguessuga marinha Stibarobdella loricata (Harding, 1924) (Hirudinea, Piscicolidae) na costa sul do Brasil, com base em sete lotes contendo 47 espécimes, entre 71 e 182 $\mathrm{mm}$ de comprimento total, coletados na região dorsal de cações-anjo, Squatina argentina (Marini, 1930), S. guggenheim Marini, 1936, Squatina punctata Marini, 1936 (Chondrichthyes, Squatinidae) e sobre a cabeça de um tubarão-mangona, Carcharias taurus (Rafinesque, 1810) (Chondrichthyes, Carchariidae). Estes são os primeiros registros de S. loricata no Atlântico ocidental e da associação parasitária com S. argentina, S. guggenheim, S. punctata e C. taurus.

Palavras-chave: Stibarobdella loricata, Squatina spp., Carcharias taurus, Hirudinea, Chondrichthyes, ectoparasitismo.

\section{INTRODUCTION}

Previous works on marine leeches in Brazilian waters are scarce and based on compilations (Pinto, 1923; Ringuelet, 1944) and single records (Soto,
2000), including hirudineans of Argentina, Brazil, Chile, Paraguay, and Uruguay. Between January 1991 and June 2001, several specimens of marine leeches were collected which had adhered to the dorsal region of coastal sharks on the Rio Grande 
TABLE 1

Lots of Stibarobdella loricata collected of the coast of Rio Grande do Sul, southern Brazil.

\begin{tabular}{|c|c|c|c|c|c|c|c|c|c|}
\hline $\begin{array}{l}\text { Coll. N. } \\
\text { MOVI }\end{array}$ & $\mathbf{n}$ & $\begin{array}{c}\mathrm{TL} \\
(\mathrm{mm})\end{array}$ & Locality & $\begin{array}{l}\text { Latitude/ } \\
\text { Longitude }\end{array}$ & $\begin{array}{c}\text { Fishing } \\
\text { modality }\end{array}$ & $\begin{array}{c}\text { Depth } \\
(\mathrm{m})\end{array}$ & Date & $\begin{array}{c}\text { Fishing } \\
\text { Vessel }\end{array}$ & Hosts \\
\hline $\begin{array}{c}01133- \\
01134\end{array}$ & 2 & $124-130$ & Off coast of Imbé & $\begin{array}{c}29^{\circ} 53^{\prime} \mathrm{S} \\
49^{\circ} 45^{\prime} \mathrm{W}\end{array}$ & $\begin{array}{c}\text { Botton } \\
\text { gillnet }\end{array}$ & 27 & $\begin{array}{c}-/ \mathrm{i} / \\
1991\end{array}$ & Laureano V & $\begin{array}{l}\text { Squatina } \\
\text { punctata }\end{array}$ \\
\hline 01724 & 1 & 120 & Off coast of Imbé & $\begin{array}{c}29^{\circ} 54^{\prime} \mathrm{S} \\
49^{\circ} 35^{\prime} \mathrm{W}\end{array}$ & $\begin{array}{l}\text { Botton } \\
\text { gillnet }\end{array}$ & 38 & $\begin{array}{l}-/ i x / \\
1991\end{array}$ & Laureano V & $\begin{array}{c}\text { Carcharias } \\
\text { taurus }\end{array}$ \\
\hline $\begin{array}{c}01735- \\
01737\end{array}$ & 3 & 162 & $\begin{array}{l}\text { Off coast of } \\
\text { Tramandaí }\end{array}$ & $\begin{array}{c}29^{\circ} 34^{\prime} \mathrm{S} \\
49^{\circ} 35^{\prime} \mathrm{W}\end{array}$ & $\begin{array}{l}\text { Botton } \\
\text { gillnet }\end{array}$ & 52 & $\begin{array}{c}-/ \text { iii/ } \\
1992\end{array}$ & Laureano IV & $\begin{array}{l}\text { Squatina } \\
\text { punctata }\end{array}$ \\
\hline 03873 & 1 & 182 & Off coast of Torres & $\begin{array}{c}29^{\circ} 34^{\prime} \mathrm{S} \\
49^{\circ} 10^{\prime} \mathrm{W}\end{array}$ & $\begin{array}{l}\text { Botton } \\
\text { gillnet }\end{array}$ & 52 & $\begin{array}{l}-/ \text {-/ix/ } \\
1993\end{array}$ & Laureano IV & $\begin{array}{l}\text { Squatina } \\
\text { punctata }\end{array}$ \\
\hline $\begin{array}{c}10780- \\
10808\end{array}$ & 29 & $71-171$ & Off coast of Chuí & $\begin{array}{c}34^{\circ} 05^{\prime} 33^{\prime \prime} \mathrm{S} \\
51^{\circ} 26^{\prime} 30^{\prime \prime} \mathrm{W}\end{array}$ & $\begin{array}{l}\text { Baited } \\
\text { trap }\end{array}$ & $\sim 200$ & $\begin{array}{l}31 / v i / \\
1995\end{array}$ & Iporanga & $\begin{array}{c}\text { Squatina } \\
\text { argentina } \\
\text { Squatina } \\
\text { guggenheim }\end{array}$ \\
\hline $\begin{array}{c}10809- \\
10818\end{array}$ & 10 & $72-137$ & $\begin{array}{l}\text { Off coast of } \\
\text { Mostardas }\end{array}$ & $\begin{array}{c}30^{\circ} 57^{\prime} 05^{\prime \prime} \mathrm{S} \\
50^{\circ} 10^{\prime} 04^{\prime \prime} \mathrm{W}\end{array}$ & $\begin{array}{l}\text { Baited } \\
\text { trap }\end{array}$ & 90 & $\begin{array}{c}24 / v i i / \\
1995\end{array}$ & Iporanga & $\begin{array}{c}\text { Squatina } \\
\text { argentina } \\
\text { Squatina } \\
\text { guggenheim }\end{array}$ \\
\hline 19521 & 1 & 83 & $\begin{array}{c}\text { Off coast of Rio } \\
\text { Grande }\end{array}$ & $\begin{array}{l}32^{\circ} 34^{\prime} 17^{\prime \prime} \mathrm{S} \\
50^{\circ} 19^{\prime} 09^{\prime \prime} \mathrm{W}\end{array}$ & $\begin{array}{c}\text { Botton } \\
\text { trawl }\end{array}$ & 300 & $\begin{array}{l}3 / \mathrm{vi} / \\
2001\end{array}$ & Saga de Thor & $\begin{array}{l}\text { Squatina } \\
\text { argentina }\end{array}$ \\
\hline
\end{tabular}

do Sul coast, and which were stored in the Invertebrate section of the Museu Oceanográfico do Vale do Itajaí (MOVI). All leeches are males 71 to $182 \mathrm{~mm}$ in total length; the hosts are subadults and adults of common sharks of the southern Brazilian coast (Table 1).

The nomenclature of the angel sharks of the Squatina complex follows Soto (2001). The ectoparasite was identified as Stibarobdella loricata (Harding, 1924) (Clitellata, Piscicolidae, Ichthyobdellinae) (Fig. 1), a typical genus and species of leech ectoparasitic on elasmobranchs, based on a dichotomous key of Llewellyn (1966) and some other particular characters presented by the same author.

The species is characterized by a fusiform body tapering gradually towards the anterior end long and circular in cross-section when fully gorged, but somewhat flattened dorso-ventrally in starved specimens. The anterior sucker is cup-shaped and attached eccentrically so that the dorsal surface is longer than the ventral. It is generally circular but may be slightly flattened laterally, so that its opening becomes slit-like. It possesses a marginal fringe and generally three pairs of inconspicuous papillae on each side. The anterior sucker is often about equal in size to the posterior sucker, but when both are fully expanded the latter is slightly larger. The anterior sucker is usually three times the diameter of its point of attachment but never exceeds the greatest diameter of the body.

The posterior sucker is cup-shaped when contracted and its diameter is then less than the greatest diameter of the body, but approximately equals it when expanded. This sucker is attached centrally and is greater in diameter than its point of attachment. The color of all specimens examined is olive green (fresh) or pale yellow (fixed). A diagram illustrating the annulation, tuberculation, and suckers of a single specimen of S. loricata is shown in Figs. 2 and 3.

The spectrum of the fish hosts include unidentified oceanic sharks and the distribution is large in circumglobal tropical waters (Llewellyn, 1966) (Fig. 4). The present paper reports the first record of Stibarobdella loricata in the western Atlantic (southern Brazilian coast) and the first identified hosts, Squatina argentina, S. guggenheim, S. punctata, and Carcharias taurus, for this marine leech. 


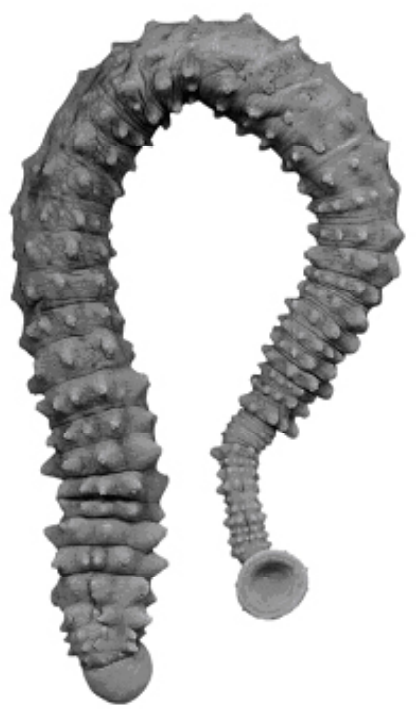

Fig. 1 - Stibarobdella loricata MOVI 03873 (male, $182 \mathrm{~mm} \mathrm{TL)} \mathrm{collected} \mathrm{on} \mathrm{the} \mathrm{dorsal} \mathrm{region} \mathrm{of} \mathrm{the} \mathrm{Squatina} \mathrm{punctata,} \mathrm{off}$ the coast of Rio Grande do Sul, southern Brazil.

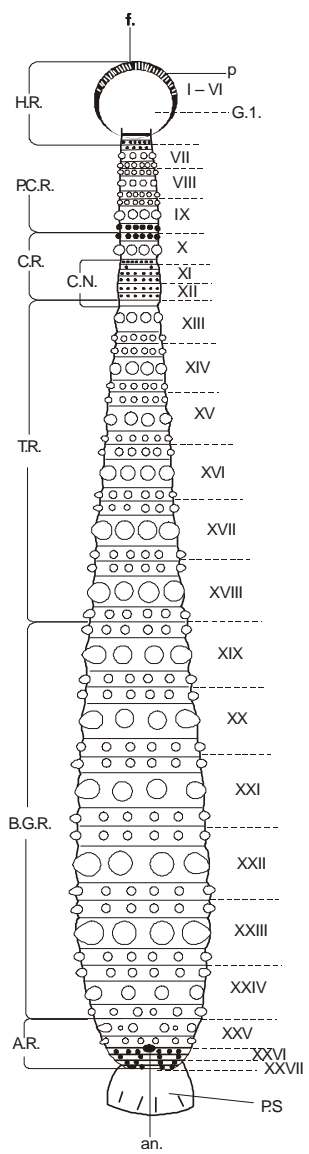

Fig. 2 - A typical Stibarobdella loricata in dorsal view, according to Llewellyn (1966). See the same author for abbreviations of annulation, tuberculation, and suckers. 


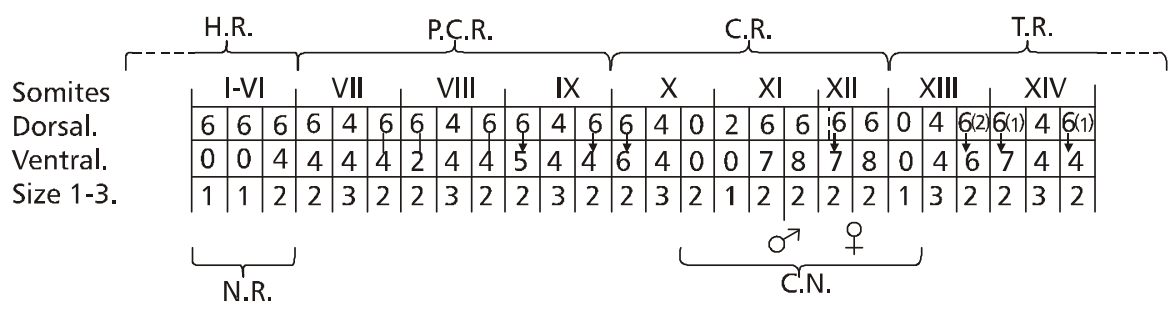

\begin{tabular}{|c|c|c|c|c|c|c|c|c|c|c|c|}
\hline & \multicolumn{4}{|c|}{ B.G.R. } & & \multicolumn{6}{|c|}{ A.R. } \\
\hline Somites & & XXIII & & KXIV & & $X>$ & KV & XXI & $\mathrm{VI}_{\mathrm{r}}$ & & KVII \\
\hline Dorsal. & 6 & \begin{tabular}{|l|l|}
$6(2)$ \\
\end{tabular} & 6 & 4 & 6 & 4 & 6 & 6 & 6 & & 4 \\
\hline Ventral. & 6(2) & $44^{5} 4$ & 6 & 4 & 5 & 4 & 4 & 4 & 4 & 2 & 0 \\
\hline Size 1-3. & 2 & \begin{tabular}{|l|l|}
3 & 2
\end{tabular} & 2 & 3 & 2 & 2 & 2 & & 1 & $1 !$ & $\frac{1}{2} !$ \\
\hline
\end{tabular}

Fig. 3 - Diagram of a typical Stibarobdella loricata, according to Llewellyn (1966). See Fig. 2 to localize the structures.

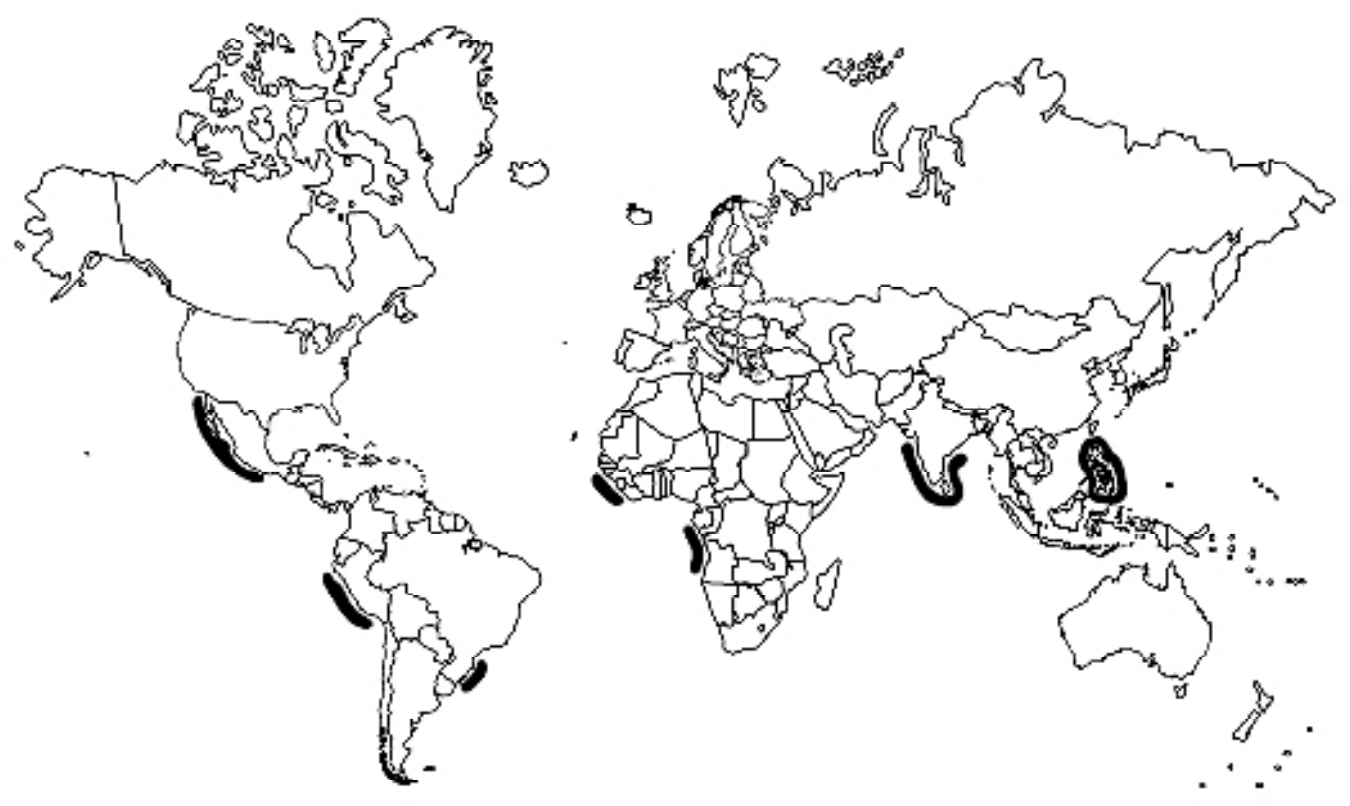

Fig. 4 - Global distribution of Stibarobdella loricata, including the new record for the southern Brazilian coast.

Acknowledgments — I am grateful to Michael Maia Mincarone, for comments on the manuscript, and Rafael de Alcantara Brandi for his work on the figures.

\section{REFERENCES}

LLEWELLYN, L. C., 1966, Pontobdellinae (Piscicolidae: Hirudinea) in the British Museum (Natural History) with a review of the subfamily. Bull. Brit. Mus. (Nat. Hist.), Zool., 14: 389-439.

PINTO, C., 1923. Ensaio monographico dos hirudineos. Rev. Mus. Paulista, 13: 853-1118.
SOTO, J. M. R., 2000, Marine leech, Stibarobdella macrothela (Schmarda, 1861) (Hirudinea, Piscicolidae), parasitic on the whaler shark, Carcharhinus brachyurus (Günther, 1870) (Chondrichthyes, Carcharhinidae), in southern Brazilian waters. Rev. Brasil. Biol., 60(4): 713-714.

SOTO, J. M. R., 2001, Annotated systematic checklist and bibliography of the coastal and oceanic fauna of Brazil. I. Sharks. Mare Magnum, 1(1): 51-119.

RINGUELET, R., 1944, Sinopsis sistemática y zoogeográfica de los hirudíneos de la Argentina, Brasil, Chile, Paraguay y Uruguay. Rev. Mus. La Plata, Nueva Serie 3, Zool., 22: $163-232$. 